\title{
Study on Land Law Enforcement Agency Team Building in Underdeveloped West China
}

\author{
Ma Qiongli \\ Public Administration College of Yunnan University of Finance and Economics \\ Kunming, P.R. China \\ (1040086919@qq.com)
}

\begin{abstract}
The main problem of this paper is to look for the ways and means of promoting land law enforcement agency team building in underdeveloped West China. The author is mainly through reading literature and field research to carry out research. Land law enforcement agency team building in underdeveloped West China is in systematic dilemma, so, the government need to reform of law enforcement system, adjust the relationship between power and responsibility, perfect legal system, Improve the quality of law enforcement officer, strengthen law enforcement protection, etc. The innovation of this paper lies in research the dilemma of land law enforcement agency team building in underdeveloped West China systematically.
\end{abstract}

Keywords-West China, land law enforcement, agency and team building

\section{LiterATURE REVIEW}

Since 1960s, foreign scholars, including Davis, Crecine, Rolleston, Peterson, Daniel, etc. have started to research on land administration of public sectors. From the late 20th century to now, Tommy, Zaslavsky, Daudelin, Wate, etc. have conducted study on land law violation governance, including land law enforcement, proposed viewpoints about occurrence of land law breaking behaviors and land law enforcement, and held the opinion that the main ways to govern land law violating behaviors of public sectors are to improve social and judicial systems, complete public power restriction mechanism, improve power exercising transparency of public sectors, enhance land resources allocation marketization, establish a set of complete land administration accountability system, etc. As the reform and opening up proceeds, land law breaking issues emerge in China. From late 20th century to now, some scholars including Jang Ailin, Liang Ruobing, Wang Weilin, Lu Rucheng, etc. have conducted intensive study on land administration and land law violations mainly in four areas: land unlawful acts, reasons, governance and land law enforcement. Scholars positively discuss how to govern land law violation, how to improve land law enforcement, and put forward quite many micro and macro governance measures. There is not quite much study at home and abroad on land law enforcement agency and team building in West China..

\section{BACKWARD AgENCY AND TEAM BUILDING IN UNDERDEVELOPED WEST CHINA IS THE SOFT SPOT FOR LAND LAW ENFORCEMENT}

Land resources are major fundamental and strategic resources decisive for long-term development of economic society and basic wellbeing of the public in underdeveloped West China, and it has an unusual position in the whole regional social economy. General situations, development paths and development stages of provinces in West China suggest that scientific land resources use and strict protection is extremely important and urgent. As industrialization, urbanization and agricultural modernization speed up and the peak population period comes, disparity between supply and demand of land is increasingly severe, growing social issues triggered by land use and development emerge, land protection situation is extremely severe, and land law enforcement is unprecedentedly important. When it is high time to powerfully enforce land laws, West China is confronted against many predicaments like "difficulty in preventing, discovering, stopping, investigating, punishing and implementing". Backward agency and team building is just the soft spot for law enforcement in West China, and all the predicaments above are closely related to it. The actual dilemma of land law enforcement agency and team building is the key reason for "difficulty in law enforcement". Since the 18th NPC, guided by important discussions on comprehensively law-based governance of President Xi Jinping, the law-based governance and government of China welcomes a brand new historic milestone. Comprehensively promoting law-based governance, and law-based administration of government put forward brand new and higher requirements for land law enforcement agency and team building in six respects, such as qualification and quality of law enforcement subject, awareness and capability of law enforcement, authority-responsibility relationship, enforcement procedure and efficiency. As the law-based governance and administration proceeds, our country's administration will be further streamlined, shifted from management-based administration to enforcement administration, the ratio of enforcement in administration is on the rise, the enforcement nature of administration will be increasingly reinforced, it will be significant to solve the difficult enforcement problem in Chinese administrative reform, and there is no exception in land administration. Once the soft spot of agency and team building is focused on, the key to get out of law enforcement predicament in West China will be seized. 


\section{ANALYSis OF PROBlEMS IN LAND LAW \\ ENFORCEMENT AGENCY TEAM BUILDING IN UNDERDEVELOPED WEST CHINA AND THE REASONS}

(I) Illegitimate agencies and personnel. Before public institution reform in 2014, land law enforcement agencies are mostly public institutions involving public administration, which are established according to legal procedures, and they perform administrative enforcement functions in the name of being entrusted by land resources administrative authority in charge. However, the administrative entrusting neither has any legal basis nor any legal procedures, so as a matter of fact, land law enforcement agencies and personnel don't have legitimate enforcement qualifications, and their enforcement acts and effectiveness are not lawful enough. After the new public institution reform gets started, land law enforcement institutions are classified into public benefit units, so the land law enforcement identity and qualification dilemma continues. There are many reasons: firstly the government hasn't realized the importance of land law enforcement, and the concept of "stressing on exam \& approval and ignoring enforcement" is deeply rooted; secondly under the semi-vertical administrative system, land administration is for local interests, and land law enforcement functions are weakened, so land law enforcement is further marginalized; thirdly the absence of land enforcement institution and team building laws, systems, policies and norms at national and provincial government levels results in no basis for land enforcement agencies to be classified into administrative institutions in the new public institution reform, so land enforcement institutions are in quite passive positions.

(II) Functions, responsibilities and power and rights are unmatched. Land law enforcement doesn't have administrative compulsory power, and in the face of increasingly severe enforcement situations, the power and rights are not enough to shoulder functions and responsibilities. The awkward situation that "illegal behaviors are not stopped, and enforcement decisions cannot be implemented" occurs in enforcement practice. The reasons are as follows: firstly the legal design has defects. Considering "separated adjudication and implementation", the law doesn't give land enforcement administrative compulsory rights of deterring administrative compulsory execution power. As for various land law violating acts, law enforcement personnel only have the rights to order stopping; secondly the policy design has defects. Within the established framework, defects of land enforcement power and duty are not made up of through policy design timely at the national level. Provinces integrate enforcement forces by establishing coordinated enforcement mechanism, joint case handling mechanism, shared responsibility mechanism, etc., take advantage of forces to enforce laws, some effects are accomplished, and they are not quite ideal.

(III) Agency teams and enforcement actions are not independent. Land enforcement departments are functional departments of people's governments of the level, and they are incapable of investigating in the face of land law violations acquiesced, connived and dominated by local governments. The reasons are as follows: firstly the management system is restricted. Land law enforcement, affiliated to local government or under semi-vertical management system, is distorted and alienated inevitably; secondly it is under the impact of lopsided development concepts and development modes. Under the comprehensive impact of work performance foremost, lopsided growth, land finance development concepts and modes, land resources is of special positions and value, and local governments of different levels control land resources rigorously. Due to its subtle relation with local GDP growth, leaders' work performance, and fiscal revenue, land law enforcement is also interfered when being marginalized.

(IV) Personnel quality and law enforcement situations are not adaptive. New situations have higher requirements for enforcement concepts, levels, capabilities, styles and comprehensive quality of land enforcement teams and personnel in underdeveloped West China. However, professional quality of some grassroots enforcement personnel is relatively low. For example, no consciousness of law-based administration of government, inadequate comprehension of laws, regulations, policies and standards, excessive arbitrariness of law enforcement procedures and discretion, simple and rude law enforcement, etc. There are two reasons. Firstly it is difficult to attract and cultivate talents. Land law enforcement work is arduous and it is quite difficult to cultivate land law enforcement cadres, land law enforcement has inadequate qualified personnel, so it is quite difficult to build a high quality law enforcement team; secondly law enforcement performance management and accountability system is incomplete. Performance management and assessment are absent, and law enforcement personnel don't have enough pressure and impetus to positively perform their duties. Due to accountability absence and vague punishment, law enforcement personnel are not aware of laws and responsibilities to enforce the law legally.

(V) Enforcement guarantee and enforcement tasks are synchronous. As the economic society develops rapidly, land interests has increasing conflicts, and law enforcement tasks are increasingly heavy, the law enforcement assurance stands still, and it is not synchronously perfected along with law enforcement duties and responsibilities. Grassroots land enforcement department personnel are severely understaffed, financial outlay is not enough, special fund for law enforcement is squeezed and embezzled, equipment like special vehicle for enforcement is in shortage, and enforcement subsidy, personal insurance and accident insurance are hard to be carried out. The reasons for these are as follows: firstly the government fails to attach enough importance. Secondly economic society develops quite slowly. Provinces in West China are where ethnic groups live, economic society is behind national average level, and 
governmental finance is limited; thirdly natural geography and humanity and customs are also reasons. There are special geographical conditions with high mountains, steep slopes, deep valleys, thick forests and inconvenient transportation in West China; legal awareness of minority groups is relatively poor, resulting in difficulty in law enforcement and high costs.

\section{Basis to Promote Land LAW ENFORCEMENT AGENCY TEAM STANDARDIZATION BUILDING IN UNDERDEVELOPED WEST CHINA}

Firstly there is inadequate policy basis to classify land law enforcement institutions to public good institutions. At present, land law enforcement institutions in underdeveloped West China are mostly classified into public good institutions, while this is unsuitable for the original intention of national public institution reforms and actual requirements of land administration. "Guiding Opinions of CPC Central Committee the State Council on Classifying and Promoting Public Institution Reform", which was published on April 16th, 2012, clearly says, "classify categories of present public institutions. Based on standardization, classify current public institutions into three categories, namely undertaking administrative functions, engaging in production and operation activities and getting involved in public good services, according to social functions. Those assuming administrative functions will gradually put administrative functions under or turn into administrative institutions", "segment public institutions engaged in public good services. Subdivide public institutions engaged in public good services into two categories according to responsibilities, tasks, service objects, resources allocation, etc.; subdivide public institutions engaged in public good services into two categories: those which undertake basic public good services, such as compulsory education, basic scientific research, public culture, public health and basic grassroots medical services, and are unable or unsuitable to get market allocation resources, are classified into public good category one; those that undertake higher education, non-profit medical care, etc. and get some market allocated resources are classified into public good category two". However, in the reform classification promoted later, public institutions involving public administration, which undertakes all administrative functions such as land enforcement, are classified into public good category one, and this is contradicting with national policies and current administrative practice, thus arousing many disputes in administrative management practice and theoretical circle. Afterwards, "Reform and Classification Catalogue of Public Institutions" published in 2014 by the State Council defines that "those meeting the following three conditions at the same time are identified as public institutions undertaking administrative functions: 1. Completely or mainly undertake administrative functions, such as exercising administrative permits, administrative penalties, administrative enforcement, administrative adjudication, etc.; 2 . Undertake administrative functions in accordance with national relevant laws or relevant central policies; 3 . If public institution of the department undertakes administrative functions, clear authorization (i.e. clearly pointing to public institutions) of relevant national laws, stipulations or relevant policies of the central government is required." Meanwhile, the catalogue clearly defines that auxiliary administrative institutions involving national land supervision, environment supervision, safe production supervision, labor security supervision, transportation supervision, cultural market comprehensive enforcement, comprehensive urban enforcement, etc. are classified into public good category one public institutions. Land law enforcement and supervision are completely different concepts in both practice and legal principles. Hence the "Classification Catalogue" fails to clearly define land law enforcement institutions should be classified into public good category one public institutions, and this leaves room for comprehensive law enforcement reforms in future.

Secondly there is inadequate basis for land law enforcement institutions to exercise administrative law enforcement rights in the capacity of public institutions. Land law enforcement institutions in underdeveloped West China are mostly public institutions, so the enforcement is developed in the name of authorization by land and resources administrative authority in charge, and the enforcement identity legality and authority is questioned. In 1996, the Ministry of Forestry asked Commission of Legislative Affairs of NPC Standing Committee "if administrative authority could decide the administrative penalty commission at its discretion", and got the reply that "Sub-clause one of clause 18 of "Administrative Penalties Law" stipulates: 'Pursuant to stipulations of laws, rules or regulations, administrative authority may entrust organizations in line with conditions stipulated in clause 19 of the law within its legal power to implement administrative penalties, and administrative authority cannot entrust other organizations or individuals to implement administrative penalty." In accordance with the stipulation, only administrative authority that laws, rules or regulations clearly stipulate, the administrative authority may entrust penalties pursuant to laws." In fact, at present the entrusted law enforcement in the land resources administration area does not have definite stipulations from laws, rules and regulations, most provincial level local people's governments and land and resources administrative departments in charge have never had any administrative entrusting in line with legal forms and procedures to land law enforcement institutions. Furthermore, although administrative penalty is the core of land administrative law enforcement, but it is not all the content in land law enforcement. "Administrative Penalties Law" stipulates entrusted enforcement in administrative penalties, but it doesn't mean that any land administrative enforcement may be entrusted. "Administrative Procedural Law of the People's Republic of China" implemented on May 1, 2015, has extended the scope of administrative subject into "organizations authorized by laws, stipulations and regulations", suggesting that local government has rights to give administrative subject qualifications to certain organization or institution. This paves the way for underdeveloped provinces in West China to change entrusted land law enforcement into authorized enforcement via legal forms (local stipulations or local government regulations).

Thirdly local governments have sufficient legal and policy basis to promote land law enforcement institution and team building. "Organization Law of Local People's Congresses and 
Local People's Governments of All Levels" stipulates "local people's governments of all levels set up necessary work departments according to work requirements and effective principles". Therefore, the local government has certain rights to set up departments, and land law enforcement sector is only an internal institution, so local governments own the sufficient power to make decisions. Issues involved in land law enforcement institution and team reforms, such as institution, manning quota, personnel, relationship between superior and subordinate, are decided by the government. It is barrier-free in legal principle to make laws appropriately or make authorization concerning land law enforcement institutions and teams according to economic society's development and management in underdeveloped West China, so as to solve organizational carrier issues in land law enforcement system reform. "Guiding Opinions of CPC Central Committee the State Council on Classifying and Promoting Public Institution Reform" stipulates that "public institutions undertaking administrative functions should be identified severely according to relevant national laws, stipulations, relevant central policies, and whether to principally fulfill administrative decisions, implementation, supervision, etc. or not. Reforms are carried out according to different situations." Promote reforms of public institutions undertaking administrative functions with regard to administrative system reforms and governmental institution reforms, especially exploring the greater department system with organic and uniform functions. If manning quota adjustment is involved, governmental institution quota and headcount limitation cannot be exceeded, and vacancies from secondment in administrative management system and government agency reforms are used to solve the issue step by step. Public institutions partially undertaking administrative functions should be organized and governmental functions should be classified into relevant administrative institutions; after the function is adjusted, define responsibilities of public institutions and classify categories once again. If the tasks are not heavy, cancel or incorporate into other public institutions. Public institutions completely undertaking administrative functions may be adjusted into internal institutions of relevant administrative authority. If it is necessary to set up administrative institution independently, the establishment should follow efficiency principles. Public institutions that are identified as undertaking administrative functions and not being adjusted well use utilities staffing quota, the headcount will not increase, human resources, financial affairs, social insurance, etc. will be implemented and administrated according to current national policies." Law enforcement institutions of all levels in underdeveloped West China are all institutions completely performing administrative functions, which are established according to legal procedures. It doesn't violate national policies for local governments to classify them into administrative public institutions or internal institutions of land and resources administrative sectors in charge in the transitional or progressive way, and it also means practically implementing comprehensive law-based state governance advocated by President Xi Jinping.

\section{CONCLUSION}

Countermeasures to strengthen land law enforcement agency and team building in underdeveloped West China are recommended as follows: firstly give legitimate identity to land enforcement institutions and personnel. Pursuant to the principle of "respecting history and facing reality", classify land institutions into administrative public institution, or change into administrative institution set up in land resources administrative sectors in charge. Under the precondition of keeping the same fiscal expenditure, change enforcement personnel quota into administrative quota or administrative public institution quota, and endow legitimate law enforcement identity to enforcement personnel; secondly enhance land enforcement teams' independency, establish land lawenforcing vertical management system, and realize vertical land law enforcement. Reduce law enforcement tiers, withdraw prefectures (cities) and give more power to counties, and original duties and responsibilities of prefecture (cities) land enforcement teams are shouldered by county level counterparts; thirdly define responsibilities, power and functions of land enforcement institutions of every level. West China completes local legal systems concerning land management within national legal framework, and land resources administrative sectors of all levels exercise enforcement functions and powers in accordance with relevant laws, stipulations and regulations, fulfill legal functions and undertake corresponding responsibilities; fourthly complete and optimize land enforcement mechanism. Establish and complete local rules and regulations of all levels concerning land enforcement supervision, prevention and prohibition, case administration, case investigation, discretion, joint trial, accountability, notification and filing, supervision and assistance, file evaluation, law enforcement responsibilities, etc., therefore laying a solid foundation for legal enforcement and standard implementation. Establish a solid enforcement mechanism, and build land enforcement supervisory long-term mechanism; fifthly strengthen law enforcement human resources management. Establish land law enforcement cadres' career development mechanism, and offer good conditions for land law enforcement personnel's business trainings, education improvement, and grassroots practice. Build the land enforcement award mechanism, and provide awards based on performance. Provide fair career promotion platforms and environment for land law enforcement personnel, and provide a good career development path for them.

\section{ACKNOWLEDGMENT}

Thanks go to public administration college of Yunnan University of Finance and Economics for providing me the chance to attend the international conference. Thank you to Department of Resources of Yunnan Province for providing data and information support. The author gets enlightenment from research fruits of domestic and overseas scholars of relevant areas. Here the most sincere thanks are extended. 


\section{REFERENCES}

[1] Lu Wenzheng, Land Administration Innovation under New Normal Situations [J]. Operator, 2015,35:353.

[2] Sui Lianfeng. On Shortcomings and Solutions of Land Management in China $[\mathrm{J}]$. Heilongjiang Science and Technology Information, 2016,02:273.

[3] Shaojia CAO, Xianshu Li. Modes for Agricultural Land Protection in China [J]. Asian Agricultural Research, 2013,03:66-69.

[4] Xiufang ZHOU, Qing CHEN, Xunqiang GONG. Analysis on Local Government's Illegal Occupation of Cultivated Land Using Game Theory [J]. Asian Agricultural Research, 2013,11:84-87.G. Eason, B. Noble, and I.N. Sneddon, "On certain integrals of Lipschitz-Hankel type involving products of Bessel functions," Phil. Trans. Roy. Soc. London, vol. A247, pp. 529-551, April 1955.

[5] Kenneth J. Meier, Nathan Favero, Mallory Compton. Social Context, Management, and Organizational Performance: When human capital and social capital serve as substitutes[J]. Public Management Review, 2016, Vol.18 (2), pp.258-277.

[6] Alexander Newman, Qing Miao, Peter S. Hofman, Cherrie Jiuhua Zhu. The impact of socially responsible human resource management on employees' organizational citizenship behaviour: the mediating role of organizational identification[J]. The International Journal of Human Resource Management, 2016, Vol.27 (4), pp.440-455. 